\title{
EVALUATION OF COSTS OF HARVESTER IN CUT AND PROCESSING OF EUCALYPTUS WOOD ${ }^{1}$
}

\author{
Larissa Nunes dos Santos ${ }^{2 *}$, Haroldo Carlos Fernandes ${ }^{3}$, Remo Macieira Figueiredo Silva ${ }^{2}$, Márcio Lopes \\ da Silva ${ }^{4}$ and Amaury Paulo de Souza ${ }^{4}$
}

\footnotetext{
${ }^{1}$ Received on 11.08.2014 accepted for publication on 27.04.2017.

${ }^{2}$ Universidade Federal de Viçosa, Programa de Pós-Graduação em Engenharia Florestal, Viçosa, Minas Gerais, Brasil. E-mail: $<$ larissa.nunes@ufv.br>and <remofigueiredo@gmail.com>.

${ }^{3}$ Universidade Federal de Viçosa, Departamento de Engenharia Agrícola, Viçosa, Minas Gerais, Brasil. E-mail: <haroldo@ufv.br>. ${ }^{4}$ Universidade Federal de Viçosa, Departamento de Engenharia Florestal, Viçosa, Minas Gerais, Brasil. E-mail: <marlosil@ufv.br $>$ and <amaurysouza@ufv.br>.

*Corresponding author.
}

\begin{abstract}
Before performing any financial analysis costs must be calculated. These costs should allow the planning and control over the use of the machines as well as the comparison between different investments alternatives since this is easily calculated. Generally the operating costs of forest harvesting machines are estimated until the maximum of 25,000 hours of work, and it is not possible to know whether the activity remains profitable thereafter or not. For this reason the objective of this study was to evaluate the costs from cutting activities and wood processing carried out by a forestry tractor harvester up to approximately 30,000 hours of work. Ten forest machines composed of two models of harvester (John Deere, model 1270D and 1470D) were used. A spreadsheet provided by a forestry company located in the state of Minas Gerais, containing the necessary data to estimate the operating cost of the machines and subsequent achievement of the sensitivity analysis was used. The operating cost was obtained by the sum of the fixed and variable costs. For sensitivity analysis the variation $\pm 20 \%$ of the most representative elements of the total cost of the machine was performed. The results for the operating cost of the harvester and forwarder was U.S. $\$ 190.85 \mathrm{~h}^{-1}$. Costs for repairs and maintenance, labor, fuel, and depreciation represented approximately $90 \%$ of the total cost of the machine. Despite the fact that the age of the machine has a direct influence on its operating cost, the costs did not behave in a linear fashion over the years.
\end{abstract}

Keywords: Forest economics; Forest harvesting; Mechanization forest.

\section{AVALIAÇÃO DE CUSTOS DO HARVESTER NO ABATE E PROCESSAMENTO DE MADEIRA DE EUCALIPTO}

\begin{abstract}
RESUMO - Antes da realização de qualquer análise financeira é necessário que os custos sejam computados. Os custos devem permitir além do planejamento e controle do uso de máquinas a comparação entre diferentes alternativas de investimento, sendo facilmente calculados. Geralmente os custos operacionais de máquinas de colheita florestal são estimados até no máximo 25.000 horas de trabalho, não sendo possível saber se atividade continua rentável após esse período. Por este motivo objetivou-se com este trabalho, avaliar os custos provenientes da atividade de corte e processamento da madeira realizada pelo trator florestal harvester até aproximadamente 30.000 horas de trabalho. Foram utilizadas 10 máquinas florestais compostas por dois modelos de harvester (John Deere, modelos $1270 \mathrm{D}$ e 1470D). Foi utilizada a planilha fornecida por uma empresa florestal situada no estado de Minas Gerais, contendo os dados necessários para a estimativa do custo operacional das máquinas e posterior realização da análise de sensibilidade. O custo operacional foi obtido por meio do somatório dos custos fixos e variáveis. Para a análise de sensibilidade foi realizada uma variação de $\pm 20 \%$ dos elementos mais representativos do custo total da máquina. Os resultados obtidos para o custo operacional médio geral do harvester foi de US\$190,85 $\mathrm{h}^{-1}$. Os custos com manutenção e reparos, mão de obra, combustivel, e depreciação representaram aproximadamente $90 \%$ do custo total da máquina. Apesar da idade da máquina ter influência direta sobre o custo operacional da máquina, os custos não se comportaram de forma linear com o passar dos anos.
\end{abstract}

Palavras-Chave: Economia Florestal; Custo anual equivalente; Taxa interna de retorno. 


\section{INTRODUCTION}

Encouraged by the introduction of tax incentive in the 60's as well as the increased demand for forest products, Brazil has become one of the most developed countries in the forest sector in the world. This is because Brazil presents high productivity and lower production cost when compared to other countries, due to the technological advances (introduction to improved genetic material and mechanization of activities) and edaphoclimatic conditions which are favorable for eucalyptus production.

In the forest sector one of the activities that generates the highest cost to the wood put in the factory is forest harvesting. This activity together with the forest transportation contributes to more than $50 \%$ of the final wood cost, making it necessary the implementation of strategies aiming the streamlining and enhancement of the cutting operations, wood extraction and transport having as an intent the increase in productivity and the reduction of costs (Minette et al., 2008), facts that are influenced by the characteristics of the forests and the type of machine used (Prada et al., 2015).

The wood cut is the initial stage of the forest harvesting and it has a great importance in the execution of the next actions. This includes the activities of felling, limbing, tracing and stacking, that is, the first stage of wood preparation (Machado, 2014). The main machine used for the execution of the forest cut in the system of short logs is the harvester. This machine has the role of felling, limbing, tracing the wood into pre-defined lengths according to the purpose of the product, being able to peel the trees as well.

The harvester has a high cost of acquisition, it requires skilled workforce, having as a decisive element to obtain profit or loss the time spent for the execution of the activity. For this reason, the forest companies usually operate in a working scheme of approximately 22 hours per day, with a lifespan for the used machines generally of four to five years. However, there are doubts regarding the economic viability of the machines after this period of time. If their efficiency is proved, the profit coming from this operation will be optimized, since the machines will continue to generate revenue for a longer time.

For this reason the aim of this paper was to evaluate the operation cost of the harvester also identifying and analyzing the most representative elements in its composition up to approximately 30,000 hours of work.

\section{MATERIALAND METHODS}

The research was carried out in a forest company, located in the State of Minas Gerais, Brazil. All the harvesters of the model John Deere (10 machines) were evaluated until the end of their lifespan ( 7 years), that is, 5 harvesters model $1270 \mathrm{D}$, and 5 harvesters model 1470D, motor John Deere 6090HTJ, with potency of 215 hp $(160 \mathrm{~kW})$ and $241 \mathrm{hp}(180 \mathrm{~kW})$, respectivelly, with traction in their six wheels and track linking the four front tyres, with John Deere head model H270 harvester.

\subsection{Cost analyses}

This analysis was carried out through accounting method, which used both estimated and real values. The costs were estimated by the methodologies proposed by FAO according to Machado and Malinovski (1988); and by Miyata. (1980) complemented by Moreira (2000), which take into consideration the fixed costs (interests over the capital invested; insurance; administrative fee; mechanic and depreciation) and variables (fuel; lubricants and grease; hydraulic oil; tires and track; cutting materials; maintenance and repairs; and workforce). In order to estimate the depreciation a residual value of $14.28 \%$ of the initial investment was considered. Since the company supplied some detailed data regarding the consumption of lubricants and grease, hydraulic oil, tires and track, cutting material, besides additional costs with workforce, some equations were formulated with the intention of estimating with more precision the costs. These equations are presented below:

\section{- Insurance}

Usually insurance is made against theft, fire and accidents. A percentage of $1.17 \%$ of the initial value of the machine was considered (Equation 1).

$$
S E=\frac{V a P e}{h f}
$$

in which

$$
\mathrm{SE}=\text { Insurance }\left(\mathrm{US} \$ \mathrm{~h}^{-1}\right) \text {; }
$$

$\mathrm{Va}=$ value of machine acquisition (US\$);

$\mathrm{Pe}=$ percentage of the insurance value over the initial value of the machine (decimal) and,

$$
\mathrm{hf}=\text { effective working hours per year }\left(\mathrm{h}^{-1}\right) .
$$

- Administrative fee

Revista Árvore. 2017;41(5):e410501 
Due to the administrative charges, a percentage over the value of the acquisition of the machine, regarding the working administration and the machine was considered. For each year a different percentage was used according to the data supplied by the company (in average $0.43 \%$ ). The cost for the administrative fee was determined according to Equation 2.

$$
T x=\frac{V a P e}{h f}
$$

in which

$\mathrm{Tx}=$ Administrative fee $\left(\mathrm{US} \$ \mathrm{~h}^{-1}\right)$;

$\mathrm{Va}=$ value of acquisition of the machine (US\$);

$\mathrm{Pe}=$ percentage of the value of the administrative fee over the initial value of the machine (decimal),

$\mathrm{hf}=$ effective working hours per year $\left(\mathrm{h}^{-1}\right)$.

- Mechanical Workshop

These were the costs destined to maintenance, preservation and installation depreciation as well as the supporting vehicles used in the field destined to the maintenance and machine repairs. For each year a different percentage over the initial value of the machine was used (4.19\% in average) according to Equation 3.

$$
O F=\frac{V a P e}{h f}
$$

in which

$\mathrm{OF}=$ Mechanic cost $\left(\mathrm{US} \$ \mathrm{~h}^{-1}\right)$;

$\mathrm{Va}=$ value of the acquisition of the machine (US\$)

$\mathrm{Pe}=$ percentage of the value of the mechanic over the initial value of the machine (decimal) and,

$\mathrm{hf}=$ effective working hours per year $\left(\mathrm{h}^{-1}\right)$.

- Lubricants and grease

The cost referring to the consumption of lubricant oils and grease from the analyzed machines was determined according to Equation 4.

$L G=C L p l$

in which

$\mathrm{LG}=$ Cost with lubricants and grease $\left(\mathrm{US} \$ \mathrm{~h}^{-1}\right)$;
$\mathrm{CL}=$ consumption of lubricants and grease per effective working hour $\left(\mathrm{L} \mathrm{h}^{-1}\right)$ and,

$\mathrm{pl}=$ price of a liter of lubricant and grease (US\$ L).

- Hydraulic oil

This was determined using Equation 5.

$$
\mathrm{Co}=\mathrm{CH} \text { po }
$$

in which

$\mathrm{Co}=$ Cost of hydraulic oil $\left(\mathrm{US} \$ \mathrm{R} \$ \mathrm{~h}^{-1}\right)$;

$\mathrm{CH}=$ consumption of hydraulic oil per effective working hour $\left(\mathrm{L} \mathrm{h}^{-1}\right)$ and,

po $=$ price of a liter of hydraulic oil (US\$ L).

- Tires/ track

Since many companies adopt measures for tire/ track reconstruction with the aim of increasing their lifespan, this cost took into consideration not only the change of old tires/ track for new ones, but also the reutilization of the reconstructed tires/ track, the replacement of the tire air chamber as well as the track links (Equation 6).

$$
P E=\frac{(N p V p)+(N c V c)}{H u}
$$

in which

$\mathrm{Pe}=$ Cost of tires/track $\left(\mathrm{US} \$ \mathrm{~h}^{-1}\right)$;

$\mathrm{Np}=$ number of tires/substituted track;

$\mathrm{Vp}=$ value resulting from the sum of the value of the change of a tire/ track by a new one or its reconstruction (US\$ unidade ${ }^{-1}$ );

$\mathrm{Nc}=$ number of substituted air chambers;

$\mathrm{Vc}=$ unit value of the air chamber $\left(\mathrm{US} \$\right.$ unit $\left.^{-1}\right)$ and,

$\mathrm{Hu}=$ effective working hours for the tire/ track (h unit ${ }^{-1}$ ).

- Harvester cutting materials

This refers to the cost regarding the expenses with sabre and harvester chain. This cost was calculated through Equation 7:

$$
M C=\frac{(N s V s)+(N c V c)}{H m}
$$


in which

$\mathrm{MC}=\mathrm{Cost}$ with cutting material $\left(\mathrm{US} \$ \mathrm{~h}^{-1}\right)$;

$\mathrm{Ns}=$ sabre saw number;

$\mathrm{Nc}=$ chain number;

Vs = value for a machine sabre saw $\left(\mathrm{US}_{\mathrm{N}}\right.$ unit $\left.^{-1}\right)$;

$\mathrm{Vc}=$ value for a machine chain $\left(\mathrm{US} \$ \mathrm{unit}^{-1}\right)$ and

$\mathrm{Hm}=$ effective working hours for the cutting material (h unit ${ }^{-1}$ ).

- Maintenance and repairs

Since this cost is outsourced the maintenance and repair costs were calculated through the sum between the costs of services provided for the execution of the activities and the parts used according to Equation 8:

$M R=\frac{S e+P e}{h f}$

in which

$\mathrm{MR}=$ Cost of maintenance and repairs $\left(\mathrm{US} \$ \mathrm{~h}^{-1}\right)$;

$\mathrm{Se}=$ servisse costs (US\$);

$\mathrm{Pe}=$ Cost with machine parts (US\$) and,

$\mathrm{hf}=$ effective working hours per year $\left(\mathrm{h}^{-1}\right)$.

- Costs with operational workforce

These were composed by the amount paid directly to the worker and the social charges, obtained through Equation 9. The cost with workforce was determined according to the methodology proposed by the FAO, according to Machado and Malinovski (1988), plus the costs with nourishment, transport, health insurance, among other benefits supplied by the worker's company.

$M O=\frac{12[(\operatorname{Sm}(1+E s))+B n]}{h f}$

in which

$\mathrm{MO}=$ Costs with workforce $\left(\mathrm{US} \$ \mathrm{~h}^{-1}\right)$;

$\mathrm{Sm}=$ monthly salary (US\$);

$\mathrm{Bn}=$ benefits (nourishment, transport etc) (US\$);

Es = social charges factor (decimal); and,

$\mathrm{hf}=$ effective working hours per year $\left(\mathrm{h}^{-1}\right)$.

\subsubsection{Machine operational cost}

This was calculated through the sum of all the costs with machinery, staff and administration (Equation 10) in dollars per hour of effective work (US\$ $\mathrm{h}^{-1}$ ), using the exchange rate of $1 U S \$=R \$ 2.2634$ from 06/02/2014.

$$
C O=C F+C V
$$

in which

$$
\begin{aligned}
& \mathrm{CO}=\text { machine operational cost }\left(\mathrm{US} \$ \mathrm{~h}^{-1}\right) ; \\
& \mathrm{CF}=\text { fixed costs }\left(\mathrm{US} \$ \mathrm{~h}^{-1}\right) ; \text { and } \\
& \mathrm{CV}=\text { variable costs }\left(\mathrm{US} \$ \mathrm{~h}^{-1}\right) ;
\end{aligned}
$$

For that, one adjusted a simple linear model for the fixed and variable costs and a third order polynomial model for the harvester, with the objective of evaluating their behavior, depending on the machines age.

\subsubsection{Production Cost per wood value}

Afterwards the cost of production per cubic meter of wood was determined, according to Equation 11.

$C P=\frac{C O}{P d}$

in which

$\mathrm{CP}=$ production cost $\left(\mathrm{US} \$ \mathrm{~m}^{3}\right)$;

$\mathrm{CO}=$ machine operational cost $\left(\mathrm{US}_{\mathrm{S} \mathrm{h}}{ }^{-1}\right)$; and,

$\mathrm{Pd}=$ machine productivity $\left(\mathrm{m}^{3} \mathrm{~h}^{-1}\right)$.

In order to determine the machine productivity (Pd) Equation 12 was used:

$P d=\frac{P a}{h a}$

in which

$\mathrm{Pd}=$ machine productivity $\left(\mathrm{m}^{3} \mathrm{~h}^{-1}\right)$;

$\mathrm{Pa}=$ machine productivity per year $\left(\mathrm{m}^{3}\right.$ year $\left.^{-1}\right)$; and,

$\mathrm{ha}=$ effective hours of work per year $\left(\mathrm{h}\right.$ year $\left.{ }^{-1}\right)$.

A second order polynomial model was used to evaluate the behavior of the production cost regarding machine age. For the evaluation of the costs behavior according to productivity and the time of operation of the harvester a simple linear model was adjusted.

Revista Árvore. 2017;41(5):e410501 
The analyses were processed using the STATISTICA 7 software.

\subsection{Sensitivity analysis}

In order to determine the minimum, average and maximum values of the most relevant variables of the harvester, a variation of $40.00 \%(20.00 \%$ for more and for less) in the values of the main components of the operation cost was considered.

\section{RESULTS}

\subsubsection{Operational Cost}

From Table 1 one can observe the years that presented less operation costs were 2007 (US $\$ 133.01 \mathrm{~h}^{-1}$ ) and 2010 (US\$ $169.92 \mathrm{~h}^{-1}$ ) and the one with the highest cost was obtained in the year 2013 (US\$271.94 $\mathrm{h}^{-1}$ ). In average the harvester operation cost was US\$ $190.85 \mathrm{~h}^{-1}$, corresponding to $87.42 \%$ of the variable costs and $12.61 \%$ of the fixed costs.

The costs with the largest representation in the general total cost were the ones having to do with maintenance and repairs, workforce, fuel and depreciation, with values in the order of $60.21 \%, 14.29 \%, 8.90 \%$ and $8.24 \%$ respectively. The costs with interests over the invested capital, insurance, administrative charges, mechanic, lubricants and grease, hydraulics oil, tires, tracks and cutting material corresponded together to $8.35 \%$.

The behavior of the fixed, variable and operational costs (US $\$ \mathrm{~h}^{-1}$ ) due to harvester age can be observed according to Figure 1. One can observe that an increase in the machine lifespan is a result of the increase of the variable costs (due to the increase in the replacement of parts, maintenance and fuel consumption) as well as operational costs. The increase in the fixed costs occurs almost in a constant way, once its main component, that is, depreciation, was calculated through a linear method. The variation of this cost is due to either the increase or reduction in the number of effective working hours in each year that was evaluated.
The regression models work according to Equations 13,14 and 15 .

$$
\begin{aligned}
& C F=20.2617+0.9411 * I D \\
& r^{2}=0.3962 \text { standard error }=0.6367 \\
& C V=101.1235+16.4145 * I D \\
& r^{2}=0.6834 \text { standard error }=6,0582 \\
& C O=41.2966+122.5207 * I D- \\
& 34.0778 * I D^{2}+3.0449 * I D^{3} \\
& R^{2}=0.8782 \\
& \text { * significant to } 5 \% \text { by test " } t \text { ". } \\
& \text { in which } \\
& \mathrm{CF}=\text { fixed cost }\left(\mathrm{US} \$ \mathrm{~h}^{-1}\right) \text {; } \\
& \mathrm{CV}=\text { variable cost }\left(\mathrm{US} \$ \mathrm{~h}^{-1}\right) \text {; } \\
& \mathrm{CO}=\text { operational cost }\left(\mathrm{US} \$ \mathrm{~h}^{-1}\right) \text {; and, } \\
& \text { ID = machine age (years) }
\end{aligned}
$$

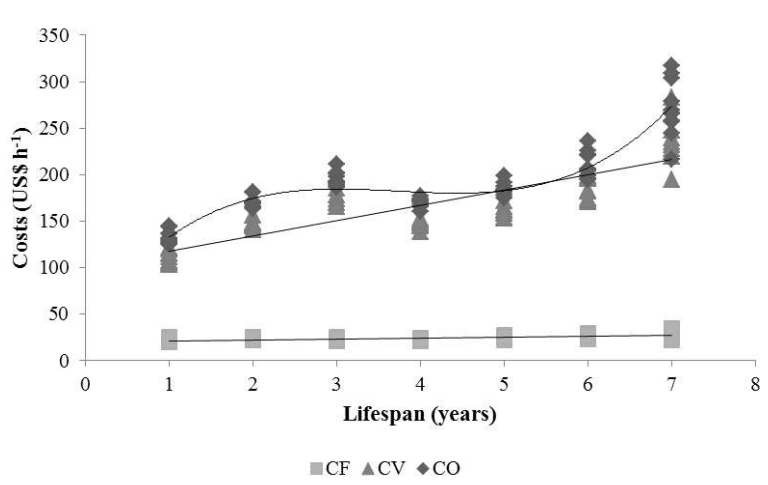

Figure 1 - Fixed costs (FC), variable (CV) and operational average $(\mathrm{CO})$ per hour of effective work of the harvester as a function of lifespan in years.

Figura 1-Custos fixos (CF), variáveis (CV) e operacionais (CO) médios por hora efetiva de trabalho do harvester em função da vida útil em anos.

Table 1 - Fixed costs (FC), variable (CV), and operational average (CO) per effective working hour of five harvester John Deere Model 1270D and five harvester John Deere Model 1470D from 2007 until 2013.

Tabela 1 - Custos fixos (CF), variáveis (CV), e operacionais (CO) médios por hora efetiva de trabalho de cinco harvester John Deere modelo 1270D, e cinco harvester John Deere modelo 1470D de 2007 à 2013.

\begin{tabular}{lcccccccc}
\hline $\mathrm{US} \mathrm{h}^{-1}$ & 2007 & 2008 & 2009 & 2010 & 2011 & 2012 & 2013 & Average \\
\hline $\mathrm{CF}$ & 22.20 & 22.93 & 22.54 & 22.39 & 24.46 & 24.64 & 29.30 & 24.07 \\
$\mathrm{CV}$ & 110.81 & 147.81 & 172.59 & 147.53 & 159.87 & 186.22 & 242.64 & 166.78 \\
$\mathrm{CO}$ & 133.01 & 170.74 & 195.14 & 169.92 & 184.33 & 210.86 & 271.94 & 190.85 \\
\hline
\end{tabular}




\subsubsection{Production cost}

The production cost found for an average productivity per hour of effective work of $24.50 \mathrm{~m}^{-3}$ was US $\$ 8.46 \mathrm{~m}^{-3}$. Simulating a decrease of $10.00 \%$ in the productivity there would be a general yearly average economy of US\$ $64,163.98$. The production cost and the average yearly productivity is shown in Table 2.

From Equation 16, it is possible to observe that the increase in the machine lifespan culminated in the increase of the production cost. The increase in the production cost in 2009 is due to the high value obtained for the maintenance and repair costs in that year.

The regression model is shown in 16 .

$$
\begin{aligned}
& C P=8.3864-2.0044 * I D+0.4050 * I D^{2} \\
& R^{2}=0.7035
\end{aligned}
$$

*significant at $5 \%$ by test " $t$ ".

in which

$\mathrm{CP}=$ harvester production cost $\left(\mathrm{US} \$ \mathrm{~m}^{-3}\right)$;

$\mathrm{ID}=$ machine age (years).

Through Equation 17 one can observe that the bigger the productivity per effective working hour the smaller the machine production cost will be. Therefore, the adequate planning for the activity execution and the operator qualification are factors of extreme importance for the cost reduction.

$$
\begin{aligned}
& C P=31.3974-0.7606 * P d-0.0013 * h f \\
& r^{2}=0.8046 \text { standard error }=1.4021 \\
& * \text { significant at } 5 \% \text { by test " } \mathrm{t} \text { ". } \\
& \text { in which } \\
& \mathrm{CP}=\text { harvest production cost }\left(\mathrm{US} \$ \mathrm{~m}^{-3}\right) \text {; } \\
& \mathrm{Pd}=\text { productivity }\left(\mathrm{m}^{3}\right) \text {; and, } \\
& \mathrm{hf}=\text { effective working hours }\left(\mathrm{h}^{-1}\right) .
\end{aligned}
$$

\subsubsection{Sensitivity Analysis}

The most influent variables in the harvester operation total cost were: effective working hours, maintenance and repairs, workforce, fuel and depreciation.

Simulating that the company is able to get a real economy of $10.00 \%$ in each of those items and an increase of $10 \%$ in the amount of effective working hours, it will be able to reduce its operational cost 2007, 2008, 2009, 2010,2011,2012, 2013 in 17.54; 18.20; 18.39; 18.08; $17.85 ; 17.14 ; 17.09 \%$, respectively. In average there would be a reduction of operational cost of $17.71 \%$.

With a reduction of $10 \%$ only for the variables of effective working hours and maintenance and repairs the company will be able to reduce in $2007-13.65 \%$; 2008 - 15.26\%; 2009 - 15.90\%; 2010 - 15.32\%; 2011 $15.02 \% ; 2012-13.59 ; 2013-13.56 \%$, that is, these are the main elements in the composition of the operational cost. In average, there would be a reduction of operational cost of $14.55 \%$.

\section{DISCUSSION}

\subsubsection{Operational Cost}

In 2007 because the machines were new, the obtained costs especially with maintenance and repairs were smaller. The reduction costs in 2010 can be explained by the average number of effective working hours $\left(4,256.41 \mathrm{~h}^{\text {ano }}{ }^{-1}\right)$ being bigger that year. In 2013, in the other hand, the high cost might have been obtained due to the increase of the variable costs, especially the costs with maintenance and repairs as well as workforce once the machines were already old and in 2012 there was in increase in the number of operators per machine to do the work during the weekends and holidays. In addition, the average number of worked hours in that year $\left(2,644.22 \mathrm{~h} \mathrm{ano}^{-1}\right)$ was significantly lower when compared to the other years.

When Leite et al. (2014), evaluated the harvester performance working in different spacing and declivity, they found different values for this work. The operation cost obtained by those authors was US\$ $145.29 \mathrm{~h}^{-1}$.

Table 2 - Productivity yield (Pd) and production cost (PC) of the harvester.

Tabela 2 - Produtividade horária (Pd) e custo de produção $(C P)$ do harvester.

\begin{tabular}{lcccccccc}
\hline & 2007 & 2008 & 2009 & 2010 & 2011 & 2012 & 2013 & Average \\
\hline $\mathrm{Pd}\left(\mathrm{m}^{3} \mathrm{~h}^{-1}\right)$ & 24.73 & 25.03 & 23.16 & 23.16 & 28.13 & 22.78 & 17.15 & 24.50 \\
$\mathrm{CP}\left(\mathrm{US} \mathrm{m}^{-3}\right)$ & 5.38 & 6.82 & 8.46 & 6.85 & 6.55 & 9.28 & 15.91 & 8.46 \\
\hline
\end{tabular}

Revista Árvore. 2017;41(5):e410501 
When Burla et al. (2012), evaluated the harvester economically under different operation conditions they also found a smaller operational cost, that is, US\$ $130.29 \mathrm{~h}^{-1}$. Fernandes et al. (2013), doing an economic evaluation of the harvester in different ground conditions and forest productivity, obtained an operational cost of US\$ 116.46 per effective working hour, where $19.00 \%$ of those costs referred to the fixed costs and $81.00 \%$ to the variable costs. The operational cost found by Martins et al. (2009), was US\$ $113 \mathrm{~m} 28 \mathrm{~h}^{-1} 68.00 \%$ of fixed costs and $32.00 \%$ of variable costs. Simões et al. (2010), obtained even smaller operational costs, that is, US $\$ 92.50 \mathrm{~h}^{-1}$ where $29.47 \%$ were fixed costs and $70.53 \%$ of variable costs.

The smallest operational cost obtained by those authors was due to the lack of measurement of some costs such as cutting material, tires and tracks, the inclusion of nourishment costs, transport and health insurance for the workers. In addition to that, generally the evaluated machines had a lifespan of the maximum 5 years.

The highest cost for maintenance and parts in 2009 can be explained by the fact that there were a bigger number of changes in machine components, thus increasing the cost. In a harvester cost analysis, Leite et al. (2013), found a percentage of the cost for maintenance and repairs, fuel and depreciation of $40.00 \%$, $20.00 \%$ and $15.00 \%$ respectively, where those were the ones with a bigger representation in the total cost. Fernandes et al. (2013), obtained a similar percentage to those authors: their result was $49.00 \%$ of the total cost.

The difference of the percentage obtained by those authors can be explained since the costs for maintenance and repairs were obtained through theoretical methodologies whereas in this paper the real value spent for the activity was used. This fact increased the cost for maintenance and parts reducing the percentage of the other items when compared to the operational cost.

\subsubsection{Production Cost}

These results are similar to the ones found by Jiroušek et al. (2007), in an evaluation of costs in the system of short logs using the harvester + forwarder in Ireland for the years 2008, 2010 and 2011. For an average productitivy of $23.69 \mathrm{~m}^{3}$ a production cost of $€ 4.93 \mathrm{~m}^{-3}$ was found, that is, US\$ $6.71 \mathrm{~m}^{-3}$. Fernandes et al. (2013) also obtained similar results for those years when they evaluated a harvester in flat areas with high productivity and in sloping areas with low population productivity where the production cost was in a range from US\$ $3.28 \mathrm{~m}^{-3}$ and US\$ $7.00 \mathrm{~m}^{-3}$.

When Costa (2012) analyzed the costs of a harvester working 3,688.44 hours per year with a productivity of $29,101.79 \mathrm{~m}^{-3}$ of wood, he obtained results that were superior to the ones found in this paper - his production cost of US $\$ 16.56 \mathrm{~m}^{-3}$. This same author found that when he increased his productivity in $10.00 \%$ he obtained a reduction in the production cost of US\$ $37,832.32$.

When Robert (2013) evaluated a mechanical harvest system in the State of Minas Gerais, Brazil, in an area of declivity ranging from 7 to $38^{\circ}$, and average productivity of $28.7 \mathrm{~m}^{3} \mathrm{~h}^{-1}$ ), he found a production cost for a harvester X3M brand Komatsu of US\$ 4.59 $\mathrm{m}^{-3}$ for a utilization rate of $60.00 \%$ and US $\$ 447 \mathrm{~m}^{-3}$ for a rate of $75.00 \%$. This result was different from the one found due to the fact that its average productivity was bigger than the one found in this paper.

Silva et al., (2014) also obtained different values for average productivity in two models of harvester (PC 200 and PC 228) of 18.57 and $19.88 \mathrm{~m}^{3} \mathrm{~h}^{-1}$, respectively. The production cost was equivalent to US $\$ 4.80 \mathrm{~m}^{-3}$ (PC 200) and US\$ $4.83 \mathrm{~m}^{-3}$ (PC 228). This happened due to it's lower operational cost, since the costs with mechanic, cutting material, tires and tracks; we're not taken into consideration. In addition, a larger number of effective operation hours $\left(5,000 \mathrm{~h} \mathrm{year}^{-1}\right)$ and a smaller number of years ( 5 years) were evaluated by those authors.

\subsubsection{Sensitivity Analysis}

The values found in this paper were similar to the ones obtained by Leite (2012), where with the reduction of $10.00 \%$ of the most relevant elements of the operational cost (machine acquisition value, maintenance and repairs, fuel price, economic lifespan, depreciation and interest rate) and an increase of $10.00 \%$ in the harvester lifespan, the company could reduce $17.00 \%$ of this cost.

Silva et al. (2014), on the other hand, in an analysis of costs of two harvesters, found as most influential production cost variables maintenance and repairs, fuel and depreciation. For this author, if a company 
is able to save $10.00 \%$ of each of those items, it might be able to reduce its production cost in $7.00 \%$.

\section{CONCLUSION}

- The highest operational cost was obtained in 2013;

- Despite the fact that the machine age influences directly the machine operational cost, the costs do not behave in a linear way through the years;

- An adoption of measures to reduce the costs with maintenance and repairs is recommended;

- The harvester should work only until its fifth year due to the high costs found after this period;

- Overall, the used methodology was efficient for the determination of the costs of forest cutting activity.

\section{ACKNOWLEDGEMENT:}

The authors would like to thank the Conselho de Desenvolvimento Científico e Tecnológico (CNPq) and the Celulose Nipo-Brasileira S. A. (CENIBRA) for the financial support and the opportunity.

\section{REFERENCES}

BURLA, E. R., FERNANDES, H. C.; MACHADO, C. C.; LEITE, D. M.; FERNANDES, P. S. Avaliação técnica e econômica do harvester em diferentes condições operacionais. Revista Engenharia na Agricultura, Viçosa, MG, v. 20, n. 5, p. 412-422, 2012.

COSTA, E. M. D. Avaliação do

desempenho e de custos de um harvester em floresta de eucalipto de baixa produtividade. 2012.85 f. Dissertação (Mestrado em Ciência Florestal) - Universidade Federal de Viçosa, Viçosa, MG, 2012.

FERNANDES, H. C.; BURLA, E. R.; LEITE, E. S.; MINETTE, L. J. Avaliação técnica e econômica de um "harvester" em diferentes condições de terreno e produtividade da floresta. Scientia Forestalis, Piracicaba, SP, v. 41, n. 97, p. 145$151,2013$.

JIROUSEK, R.; KLVAC, R.; SKOUPY, A.

Productivity and costs of the mechanised cut-to- length wood harvesting system in clear-felling operations. Journal of Forest Science, v. 53, n. 10, p. 476-482, 2007.

LEITE, E. D. S. Modelagem técnica e econômica de um sistema de colheita florestal mecanizada de toras curtas. 2012. 130 f. Tese (Doutorado em Engenharia Agrícola) - Universidade Federal de Viçosa, Viçosa, MG, 2012.

LEITE, E. D. S.; FERNANDES, H. C.; MINETTE, L. J.; LEITE, H. G.; GUEDES, I. L. Modelagem técnica e de custos do harvester no corte de madeira de eucalipto no sistema de toras curtas. Scientia Forestalis, Piracicaba, SP, v. 41, n. 98, p. 205 $215,2013$.

LEITE, E. D. S.; MINETTE, L. J. FERNANDES, H. C.; SOUZA, A. P.; AMARAL, E. J.; LACERDA, E. G. Desempenho do harvester na colheita de eucalipto em diferentes espaçamentos e declividades. Revista Árvore, Viçosa, MG, v. 38, n. 1, p. 000-000, 2014.

MACHADO, C. C. Colheita florestal. 3. ed. . Universidade Federal de Viçosa: Viçosa, MG, 2014. 543 p.

MACHADO, C. C.; MALINOVSKI, J. R. Ciência do trabalho florestal. Viçosa, $\mathrm{MG}$ : Universidade Federal de Viçosa, 1988. 65 p.

MARTINS, R. J.; SEIXAS, F.; STAPE, J. L. Avaliação técnica e econômica de um harvester trabalhando em diferentes condições de espaçamento e arranjo de plantio em povoamento de eucalipto. Scientia Forestalis, Piracicaba, SP, v. 37, n. 83, p. 253-263, 2009.

MINETTE, L. J.; SOUZA, A. P.; SILVA, E. P.; MEDEIROS, N. M. Postos de trabalho e perfil de operadores de máquinas de colheita florestal. Revista Ceres, p. 066-073, 2008.

MOREIRA, F. M. T. Análise técnica e econômica de subsistemas de colheita de madeira de eucalipto em terceira rotação. 2000. 148 p. Dissertação (Mestrado em Ciência Florestal) - Universidade Federal de Viçosa, Viçosa, MG, 2000.

PRADA, M.; ALONSO, C., M.; GARCÍA, S. S.;

Revista Árvore. 2017;41(5):e410501 
CANGA, E. Analysis of three forest chippers: productivity, costs and GHG emissions in Northern Spain. Journal of Cleaner Production, v. 101, p. 238-244, 2015.

ROBERT, R. C. G. Análise técnica e econômica de um sistema de colheita mecanizada em plantios de Eucalyptus spp. em duas condições de relevo acidentado. 2013. $113 \mathrm{f}$. Tese (Doutorado em Engenharia Florestal) - Universidade Federal do Paraná, Curitiba, PR, 2013.
SILVA, E. N.; MACHADO, C. C.; FIEDLER, N. C.; FERNANDES, H. C.; PAULA, M. O.; CARMO, F. C.; MOREIRA, G. R.; COELHO, F. E. Avaliação de custos e ambiental de dois modelos de harvester no corte de eucalipto. Ciência Florestal, Santa Maria, v. 24, n.3, p. 741-748, 2014.

SIMÕES, D.; FENNER, P. T.; BANTEL, C. A. Custos e rendimentos operacionais da extração de madeira de eucalipto com cabo aéreo. Revista Cerne, Lavras, MG, v. 16, n. 2, p. 185-192, 2010. 